\title{
Revisiting the Hackman and Oldham Job Characteristics Model and Herzberg's Two Factor Theory: Propositions on How to Make Job Enrichment Effective in Today's Organizations
}

\author{
Marwa Moses Siruri and Stephen Cheche
}

\section{ABSTRACT}

\begin{abstract}
In the increasingly competitive business landscape of today's world, human resource management ought to optimize on the organization's most important resource, the human resource, to maintain competitiveness. Such is possible through continually building into the motivation and job satisfaction of employees. While attaining both motivation and job satisfaction would ordinarily require different approaches, one of the most fundamental of approaches is through job enrichment interventions. This paper thus sequentially argues from propositions of two widely acclaimed theories viz the job characteristics model and the Herzberg's two factor theory that the creation of good work environments, regularly enhancing employee's skills and applying inspirational motivation and individual consideration could lead to success of job enrichment interventions, thereby leading to enhanced employee motivation, enhanced job satisfaction, and enhanced organizational performance.
\end{abstract}

Keywords: Herzberg's Two Factor Theory, Job Characteristics Model, Job Enrichment.

\section{BACKGROUND}

Job enrichment is a work redesign strategy that aims at increasing the motivation potential of jobs, mainly through making jobs more interesting [1]. It has equally been seen to be an approach for enhancing employee job satisfaction [2]. Other generally agreed upon benefits of enriching jobs include its ability to meet an employee's psychological, social and other lower level needs in the Maslow's hierarchy, thus leading to enhanced productivity at an individual's level of analysis [3], reduced employee absenteeism, reduced employee-supervisor conflicts, and reduced employee boredom [4].

Empirical studies such as that of [5] have established positive correlations between job enrichment and organizational performance. [6] and [1] also suggest that several other studies have reported a positive relationship between job enrichment and organizational performance, especially in sectors such as assembly lines, consulting, nursing, and manufacturing.

Contradicting findings on the effect of job enrichment on individual and organizational outcomes are nonetheless common place in empirical literature as well [7]. One such example is where [8] in an empirical study reported a nonsignificant beta value on the effect of job enrichment on performance of commercial banks in Kenya.

Reasonably, the contradicting findings on the effect of job enrichment on organizational performance may be attributed to the fact that some studies map job enrichment directly to
Submitted : February 24, 2021

Published : April 13, 2021

ISSN: $2507-1076$

DOI: $10.24018 /$ ejbmr.2021.6.2.767

\section{M. Siruri*}

Corporate Relationship Manager, KCB Bank Kenya Limited, Kenya.

(e-mail: marwasiruri@ gmail.com) S. Cheche

Consultant and Trainer in Human Resource Management, Kenya. (e-mail: chechestephen ${ }^{\circledR}$ gmail.com)

*Corresponding Author organizational outcomes, whereas as a job redesign intervention, the primary level of target for job enrichment is the individual and group, not the organization [6]. Even so, a conundrum exists on the contradicting findings as it is a truism in human resource management studies that improvement in individual employee performance should indeed in tandem lead to enhanced organizational performance, hence if job enrichment leads to enhanced individual performance, it should be able to lead to enhanced organizational performance as well.

Human resource practitioners and departments unfortunately find themselves with a number of challenges in the quest of driving enhanced organizational performance [9]. Some of these challenges include those that require close balancing between the need to meet individual employee needs and the growth needs of the organization [4]. The intersection of these may perhaps be in the understanding of the relationship between structure, including job structures, and the goals of the organization [10].

Formal structures essentially communicate the realism that organizational goals have been clearly defined and the criteria of achieving them properly identified [10] which regrettably may not necessarily be true. Even so, more generally, structures are concerned with the distribution of jobs and lines of command, thereby placing them within the domain of managerial responsibility, hence bringing to the fore the need for sound goal attainment approaches even in the design of jobs [10]. 
The key assumption in goal attainment approaches is that organizations are deliberate, rational and goal seeking entities [11]. Operationalizing these assumptions in organizations is however fraught with many problems, as ambiguities usually exist in the definitions of goals. Setting out goals in very specific terms may consequently be a remedy, as doing so helps build consensus on what the goals are and what is the role of management and the role of the rest of the employees in attaining the goals [11]. Such building of congruence in expectations on what the actual organizational goals are is indeed an indispensable ingredient in the design and redesign of work [12].

\section{A. Theoretical Perspectives on Design of Work: The Job Characteristics Model}

The Job Characteristics Model, as proposed by Hackman and colleagues [13] is arguably one of the most prominent models that has been used to understand the philosophy of job designs. [13] in the model propounded that there are five dimensions of jobs that are core in defining three psychological states important to individual and work outcomes. These five dimensions of jobs are skill variety, task significance, task identity, autonomy, and feedback.

Skill variety refers to the degree to which the job requires that different activities be done to enable job completion, with the activities expected to require application of multiple or different skills to execute. Task significance on the other hand refers to the degree to which the job has an impact on other people, who may be within the organization or without. Task identity, according to the model, relates to the degree to which a job requires completion of a whole task, from beginning to the end, with visible outcomes. Task autonomy on the other hand refers to the degree to which a job holder has discretion to carry out his work freely, including determining the procedures of how to carry it out. Lastly, job feedback relates to the ability of work activities providing clear and direct feedback to the individual on performance [13].

The five core dimensions notwithstanding, the model additionally proposes that an individual can attain high work motivation if three psychological states are attained. These psychological sates are experienced responsibility for work outcomes, experienced meaningfulness of work and knowledge of the results of work [13]. Experienced responsibility for work outcomes means that an individual feels personally accountable for the work they have done. Experienced meaningfulness of work on the other hand refers to the feeling by an individual that the job done is valuable to them. Lastly, knowledge of the results of work entails the person doing the job knowing adequately how he or she is effectively doing their work. All these three psychological states must be present if the desirable outcomes of enriched jobs are to be attained [13].

[14] posits that it is possible to directly relate the five job characteristics to the three key psychological states, especially given that skill variety, task identity and task significance have an effect on an individual experienced meaningfulness of work, autonomy has an influence on experienced responsibility for work outcomes while feedback leads to knowledge of the results of work.

[1] however argues that not every employee desires the challenge and responsibility of doing enriched jobs, an argument also fronted by several other authors such as [15], [16] and [17]. [1] consequently emphasizes that in designing enriched jobs, it is essential to also consider the moderators depicted in the job characteristics model, that is, employee knowledge and skill, employee growth need strength and context satisfaction.

Knowledge and skill in the perspective of the job characteristics model refers to the capabilities of the individual tasked to undertake enriched jobs, an important consideration as inadequacy on the side of the individual may lead to stress, frustration, and job dissatisfaction [1]. Growth needs strength on the other hand refers to the degree an employee desires the opportunity for personal accomplishment at work, while context satisfaction refers to the degree to which an employee is satisfied with aspects of their job such as quality of supervision, salary, working conditions, and relationship with supervisors and coworkers [1] which indeed are all hygiene factors in Frederick Herzberg's Two Factor Theory [1].

\section{B. The Herzberg Two Factor Theory, Employee Motivation and Job Satisfaction}

The Herzberg Two Factor Theory is a central content theory of motivation as it captures both motivation and job satisfaction in a single model. The theory was proposed by Frederick Herzberg and suggests that employee motivation is defined by two factors: hygiene factors and motivation factors [18] and these factors determine an employee's attitude towards work and job performance [19].

Motivation factors relate to job content and are intrinsic factors that increase an employee's job satisfaction [19]. Examples of motivation factors include responsibility, achievement, autonomy, recognition, and the job itself [8]. These motivation factors have been argued to directly tie to the job characteristics model. For instance, from the arguments of [20], the factor of achievement has an implication of job feedback, the factor of work itself has an implication of task identity and the factor of responsibility has an implication of job autonomy, all these being core characteristics in the job characteristics model. Moreover, Growth Need Strength as a moderator in the job characteristics model is also fundamentally same as the motivation factors in the Herzberg's Two Factor Theory [1].

Hygiene factors on the other hand are extrinsic factors and are argued to lead to employee job dissatisfaction [19]. Examples of hygiene factors are those relating to job context such as working relationships with subordinates and peers, including how information and feedback is relayed, salary, relationship with subordinates, work conditions including the physical conditions and facilities one works in, status and job security [20]. These, from [1] arguments on moderators in the job characteristics model, relate to context satisfaction.

[10] posit that in addition to addressing employee motivation, the theory goes further to describe how jobs are to be designed to attain employee job satisfaction. Tying job satisfaction as envisaged by Herzberg's Two Factor Theory to job satisfaction as an outcome in the Job Characteristics Model hence becomes a plausible possibility. An attempt on this nexus includes the arguments of [21] who argues that the concept of job satisfaction in job redesigns is primarily related to how well an employee meets and exceeds job 
related expectations, which is typical of feedback as captured in the Job Characteristics Model.

\section{EMPIRICAL FINDINGS ON THE EFFECT OF JOB ENRICHMENT ON INDIVIDUAL AND ORGANIZATIONAL OUTCOMES}

Empirical studies have been undertaken across many settings to establish the effect of job enrichment on individual and organizational outcomes. Conflicting findings have been found therefore indicating a need for continued research on the subject. Nevertheless, a number of these job enrichment studies seem to have a confluence that job enrichment has a positive effect on individual and organizational outcomes. Some of these studies are discussed herein in an annotated review of literature.

[8] undertook a study to understand the effect of job enrichment on performance of commercial banks in Kenya. Forty commercial banks were considered in a bank wide census study. A blend of cross sectional and descriptive research designs was adopted. Responses from three hundred and eighty-eight questionnaires were analyzed using regression techniques. The study established that job enrichment as a technostructural intervention does not have a statistically significant effect on the performance of commercial banks in Kenya.

[22] sought to establish the effect of job enrichment on organizational commitment in staff of the Regional Office of the Directorate General of State Assets Management of Bali and Nusa Tenggara in Indonesia. The sample constituted of forty-two staff from whom questionnaires were administered. Analysis of the questionnaires using partial least squares established that job enrichment has a positive effect on organizational commitment of staff of the Regional Office of the Directorate General of State Assets Management of Bali and Nusa Tenggara in Indonesia.

[23] sought to establish the effect of job enrichment on job satisfaction and performance of civil servants in Indonesia. The study sample was from civil servants working for the department of health in Sinjai Regency, South Sulawesi Province. Responses in one hundred and seventy-one questionnaires were analyzed using Structural Equation Modeling (SEM) and results showed that job enrichment has a significant effect on performance of civil servants working for the department of health in Sinjai Regency, South Sulawesi Province.

[24] undertook a study to establish the effect of job enrichment on individual performance of staff of a private university in India. A sample size of fifty-six program and divisional chairs was taken using stratified random sampling techniques, and multiple regression techniques were used as the analytical techniques. The study established that job enrichment has a significant effect on individual performance of staff of the private university in India.

[25] investigated the relationship between job enrichment and performance of nurses in Tehran, Iran. The job diagnostics survey instrument was used to collect data from one hundred and sixty nurses working in Taleghani hospital, Tehran. Inferential analysis was done, and the results indicated that there is no statistical significant relationship between job enrichment and performance of nurses in
Taleghani Hospital, Tehran, Iran.

[26] undertook a study to establish the effect of job enrichment on employee performance in commercial banks in Kisumu city, Kenya. The study adopted a cross sectional survey research design and a random sample of two hundred and ninety-seven bank staff of commercial banks in Kisumu was used. Primary data was collected using questionnaires and interview schedules. The study established that task variety, task identity, and task significance have an effect on performance of employees of commercial banks in Kisumu, but that task autonomy does not have an effect on employee performance in employees of commercial banks in Kisumu.

[5] investigated the relationship between job enrichment and organizational performance among non-academic staff in Nigerian public universities. The study adopted a descriptive research design approach and questionnaires were issued and completed by staff of public universities in Ogun State, Nigeria. The research adopted a blend of stratified and simple random sampling methods. Data was analyzed using correlation analysis, where it was established that there exists a positive correlation between job enrichment and organizational performance.

[27] undertook a study to understand the impact of job enrichment on job satisfaction of employees of Ogun State Polytechnics, Nigeria. The study adopted a blend of descriptive and cross-sectional research designs. A sample of one hundred and seventy-three staff was determined using random sampling techniques. Responses from questionnaires were analyzed using multiple regression techniques. The study established that there is a significant positive relationship between job enrichment and job satisfaction among employees of Ogun State Polytechnics, Nigeria.

\section{How TO MAKE JOB ENRICHMENT OPERATIVE IN TODAY's ORGANIZATIONS}

The empirical studies reviewed and presented in this paper largely suggest that there is unanimity in thought that job enrichment has an effect on employee performance, job satisfaction, employee commitment, among other individual and organizational outcomes, in multiple settings. Consequently, it is useful to build on the findings of these empirical studies to build a case of how to make job enrichment operative in today's organizations, while anchoring the propositions from the arguments of the Job Characteristics Model and Herzberg's Two Factor Theory. Some of these propositions, that is, creation of good working environments, regularly training employees and adopting inspirational motivation and individual consideration, are discussed, in the succeeding sections.

\section{A. Creation of Good and Safe Working Environments}

Working conditions have been postulated in the Herzberg two factor theory to be hygiene factors. Therefore, unfavorable work conditions can be detrimental in employee motivation and task performance. In view of this, job enrichment interventions may not achieve their intended purposes if the employee work environment is largely not supportive of the interventions.

One aspect of the work environment important in making job enrichment operative in today's organizations is 
employee relationships, which in a broad scope includes supervisor-subordinate relationships and employeeemployee relationships [28]. Understanding social interactions at the workplace thus becomes a mandatory necessity, as social interactions help make sense of patterns in organization behavior, thereby helping decrypt how tasks and goals can be attained in organizations [10].

[10] argue that one of the strategic essentials of building social interactions is an organization's repertoire of elements. Repertoire of elements in the context of organization behavior relates to communication in the organization, which may be verbal, such as acceptance or rejection, or nonverbal, such as frowning and smiling. For that reason, it is important to build good and open communication among employees as it helps to build social interactions in the organization which in turn helps to create healthy work environments [29] that are favorable for undertaking job enrichment interventions.

[10] in addition argue that environmental settings can also be used as a strategy of enhancing social interactions at the workplace and cite examples of such environmental settings to include an organization's physical layout, furniture, privacy, crowding, among others. [30] argues that these environmental factors can actually lead to creation of a stressful working environment that is demotivating to employees, which then may not be ideal in the undertaking of job enrichment interventions. As important, studies such as those of [31] and [32] have indicated that in the absence of good working environments, job enrichment interventions can be catastrophic and lead to workplace hazards and workplace related injuries.

\section{B. Regularly Enhance Employee Skills through Training and Development}

Training of employees on task enhancement skills is considered an imperative requisite in job enrichment interventions as it targets a key core characteristic in the job characteristics model, that is, skills variety. This is because training employees directly enhances skills and competence for both current and future jobs [33] thereby facilitating success of job enrichment interventions.

Training has also been found to have a positive effect on job satisfaction and employee performance [34] which are desirable outcomes in job enrichment interventions. Moreover, training enhances employees' motivation [35] which may then assist in employees positively taking up enriched jobs, which would discernibly not be in the case of demotivated employees.

[35] are also seen to emphasize on the need of a proper training environment if the benefits of training interventions are to ensue in an organization. Such an environment is most prominently characterized by feedback on training needs and gaps [35] which is considered an important input in the enrichment of jobs. This is because with such feedback, jobs can be redesigned in innovative ways to reduce monotony and repetitiveness, which are in actual sense the noxious aspects of jobs targeted in job enrichment interventions [3].

To execute task enhancement skills training, it is important to address a few first principles such as having employees being active participants in the learning process and designing the training to target aspects related to the requirements of the skills of the job [36]. With such a properly planned and executed training, it would be possible to address the concerns around knowledge and skills of employees, which is an indispensable moderator in the job characteristics model [1].

\section{Apply Inspirational Motivation and Individualized Consideration}

An important aspect of job enrichment interventions, as argued in the job characteristics model, is feedback. This brings into perspective the subject of how the feedback process should be. Whereas the same can be answered from various stances, the use of inspirational motivation and individualized consideration as adapted from transformational leadership styles can be one of the strategies to ensure that the feedback given is not just timely and accurate, but also is given in a manner that leads to enhanced employee motivation for the individual undertaking the enriched jobs.

Inspirational motivation and individualized consideration are two of the four characteristics of transformational leaders as espoused in the transformational leadership styles, with the other two being idealized influence and intellectual stimulation [37]. [37] espouses that these four fundamental characteristics exhibited by transformational leaders are important on many organizational outcomes. Studies such as those of [38]-[41] have also established that overall, transformational leadership styles have a statistically significant effect both as a moderator, and as a causal variable, in a number of organizational outcomes.

Inspirational motivation refers to the degree to which a leader defines the corporate vision and mission in a way that exudes enthusiasm from followers, through lifting up the workers' awareness of the organization's mission and vision and creating confidence in the followers that the vision and mission can indeed be achieved, thereby arousing the followers to accept and commit to achieving the same [42]. Individualized consideration on the other hand is the attribute of a transformational leader that enables the leader to focus on the needs and potential of followers in an individualized and respectful manner, hence creating a good organizational climate that helps achieve appropriate organizational outcomes [43].

As individual differences have been argued to be a moderator in the Job Characteristics Model, it is reasonable to hypothesize that applying inspirational motivation and individualized consideration as adapted from transformational leadership styles can lead to enhanced success rates of job enrichment interventions. This may be through appraising the individual strengths of employees before committing them to enriched jobs and giving employees feedback on their task performance in a personalized but motivating way.

\section{SUMMARY AND CONCLUSIONS}

An ample majority of job enrichment studies point to the fact that job enrichment interventions can lead to enhanced organizational performance through the positive effects that the interventions have on job satisfaction and employee motivation. Conceptual literature also suggests that job enrichment has some additional benefits which include 
enhanced employee commitment, reduced absenteeism, reduced employee turnover, among other benefits.

To most effectively apply job enrichment interventions in organizations, it is incumbent to understand the guiding principles of job enrichment, from the perspective of theory. The most celebrated theories on job enrichment are the Job Characteristics Model and the Herzberg Two Factor Theory. These two theories, when juxtaposed, indicate that there are some prerequisites that are mandatory in the design of enriched jobs.

This paper accordingly argues that the creation of good work environments, continuously training employees and adopting inspirational motivation and individualized consideration can be some of the strategies that can be used to enhance the success rate of job enrichment interventions. This is because creation of good work environments can assist in redressing hygiene factors in the two factor theory, continuously training employees can address issues relating to skill variety in the job characteristics model while adoption of individualized consideration and inspirational motivation can help address the issues of feedback and individual differences as advocated for in the job characteristics model.

These propositions are not necessarily seminal as they may have to be backed up by well-designed empirical studies. However, they can be used to guide discourses, and debate, in both academia and practice. And whereas the primary objective of this paper was contextualizing the arguments of the Herzberg Two Factor Theory and the Job Characteristics Model to today's practice of human resource management, the propositions may also inform a research agenda as presented, holding them as moderating variables in studies relating job enrichment to individual and organizational outcomes.

\section{REFERENCES}

[1] Lunenburg, F.C. (2011). Motivating by Enriching Jobs to Make Them More Interesting and Challenging. International Journal of Management, Business, And Administration. 15(1).

[2] Sarika, S. (2014). Role of Job Enrichment and Job Enlargement in Work Life Balance. Global Journal of Finance and Management. 6(3), 239-244.

[3] Siruri M. M. and Muathe S.M. (2014). A Critical Review of Literature on Job Designs in Socio-Technical Systems. Global Journal of Commerce and Management Perspective. 3(6).

[4] Huczynski, A. and Buchanan, D. (2007). Organizational Behavior. (6th Ed). Harlow: Prentice Hall.

[5] Salau, O.P., Adeniji, A. A. \& Oyewunmi, A. E. (2014). Relationship Between elements of job enrichment and organizational performance among the non-academic staff in Nigerian public universities. Marketing and Management Journal. 12 (2), 173-189.

[6] Cummings, T.G., \& Worley, C.G. (2009). Organization Development and Change (9th Ed.). Mason, OH: South-Western.

[7] Pierce, J. R., \& Aguinis, H. 2013. The too-much-of-a-good-thing effect in management. Journal of Management. 39: 313-338.

[8] Siruri M. M., Namusonge, M. J., \& M. Kilika, J. (2019). Influence of Technostructural Interventions on Performance of Commercial Banks in Kenya. International Journal of Scientific Research and Management. 7(6).

[9] Corine., Rory, E., David, P.L. \& Paul, B. (2018). Integrating Strategic Human Capital and Strategic Human Resource Management. The International Journal of Human Resource Management.29(1).34-67.

[10] Fincham, R. \& Rhodes, P. (1999). Principles of Organization Behavior. Oxford University Press: New York.

[11] Robbins, S.P. (1990). Organization theory. Prentice Hall .3rd Ed.

[12] Emmanuel Ejikeme Isichei \& Isaac Ayanyinka Ayandele, 2017. "Operational Work System Design and Staff Performance in the Nigerian Construction Industry," Entrepreneurial Business and
Economics Review, Centre for Strategic and International Entrepreneurship at the Cracow University of Economics., vol. 5(1), pages $187-200$.

[13] Hackman, J. R., and Oldham, G. R. (1980). Work redesign. Reading, MA: Addison- Wesley.

[14] Faturochman, M.A. (1997). The Job Characteristics Theory: A Review. Bulletin Psikologi.5(2).

[15] Pollert, A. (1991). The orthodoxy of flexibility. In A. Pollert, and A Pollert (Ed.), Farewell to flexibility? Oxford: Basil Blackwell.

[16] Delbridge, R., Turnbull, P. \& Wilkinson, B. (1992). Pushing back the frontiers; management control and work intensification under JIT/TQM Regimes. New technology, Work and employment. (7),97106.

[17] Sewell, G., \& Wilkinson, B. (1992). Someone to watch over me; surveillance, discipline and just in time labor process. Sociology. 26(2), 271-289.

[18] Herzberg, F. (1968). One more time: How do you motivate employees? Harvard Business Review, 46, 53-62.

[19] Yusoff, W. F. W., Kian, T. S., \& Idris, M. T. M. (2013). Herzberg's two-factor theory on work motivation: Does it work for today environment. Global Journal of Commerce \& Management Perspective. 2 (5), 18-22.

[20] Ruthankoon, R., \& Ogunlana, S.O. (2003). Testing Herzberg's TwoFactor Theory in the Thai Construction Industry. Engineering, Construction and Architectural Management. 10(5), 333-342.

[21] Hutabarat, Wesly (2015). Investigation of Teacher Job-Performance Model: Organizational Culture, Work Motivation and Job-Satisfaction. Asian Social Science.11(18),295-304.

[22] Marta, I. A., \& Supartha, W. G. (2018). The Effect of Job Enrichment and Employee Empowerment to Organizational Commitment with Work Motivation as A Mediation. International Journal of Economics, Commerce and Management, 1(4), 494-506.

[23] Benna, M.T, Brahmasari, I. A \& Nugroho, R. (2017). The effect of job enrichment, self-efficacy and organizational commitment on job satisfaction and performance of civil servants of Department of Health, Sinjai Regency, South Sulawesi Province. International Journal of Business and Management Invention. 6(2).49-64.

[24] Vijay,V.M \& Indravevi, R.(2015). A Study on Job Enrichment and Individual Performance among Faculties with Special Reference to a Private University. Mediterranean Journal of Social Sciences.6(1)252 260.

[25] Masoudi, I.A, Nazari, A \& Raadabadi, M. (2015). Examining the Relationship between Job Enrichment and Performance: A Case Study of Nurses. Asian Social Science. 11 (18).

[26] Opiyo, Ochieng and Owuor (2014). Effect of Job Redesign on Employee Performance in Commercial Banks in Kisumu, Kenya Greener Journal of Business and Management Studies. 4 (4), 115-137.

[27] Aninkan, D. O. (2014). The impact of reward management and job enrichment on job satisfaction among employees in the Ogun State Polytechnics. International Journal of Business and Management Invention.3(3), 19-26.

[28] Parvin, M.M. (2011). Factors Affecting Employee Job Satisfaction of Pharmaceutical Sector. Australian Journal of Business and Management Research .1 (9). 113-123.

[29] Samantaray, S. (2014). Use of storytelling method to develop spoken English skill. International Journal of Language \& Linguistics, 1(1), 40-45.

[30] Chandrasekhar, K. (2011). Workplace environment and its impact on organizational performance in public sector organizations. International Journal of Enterprise Computing and Business Systems.1(1).

[31] Ashkenazy, P. (2001). Innovative workplace practices and occupational injuries and illnesses in the United States. Economic and Industrial Democracy. 22(4),485-516.

[32] Brenner, M.D., Fairris, D., \& Ruser,J.W.(2004). Flexible work practices and occupational safety and health: exploring the relationship between cumulative trauma disorders and workplace transformation. Industrial relations. A journal of economy and economy.43(1).242 266.

[33] Falola, H.O, Osibanjo, A.O \& Ojo, S.I. (2014). Effectiveness of training and development on employees' performance and organization competitiveness in the Nigerian banking industry. Economic Sciences.7(56).

[34] Maaly, M. A, Al-rifai, A \& Momany, M.O. (2015). Training and its Impact on the Performance of Employees at Jordanian Universities from the Perspective of Employees: The Case of Yarmouk University. Journal of Education and Practice.6(32).

[35] Zahra, S., Iram, A. \& Naeem, H. (2014). Employee Training and Its Effect on Employees' Job Motivation and Commitment: Developing 
and Proposing a Conceptual Model. Journal of Business and Management.16(9).60-68.

[36] Samar, N. K., Morsy, M.A., Ahmed, G. S, Nabil A. A. (2016). Impact of Effective Training on Employee Performance in Hotel Establishments. Journal of Faculty of Tourism and Hotels, Fayoum University.10 (1).

[37] Burns, J.M. (2010). Leadership. New York City, NY: Harper Perennial.

[38] Siruri M. M., Namusonge, M. J., \& M. Kilika, J. (2019). The Moderating Effect of Leadership Styles in the Relationship between Employee Commitment and Performance of Commercial Banks in Kenya. The International Journal of Business \& Management. 7(6).

[39] Subramanian, I.D., Arumugam, T. \& Akel, A.B.A. (2014), Demographic and Family Related Barriers on Women Managers' Career Development. Asian Social Science. 10(1).

[40] Almutairi D.0. (2013). The relationship between leadership styles and organizational commitment: a test on a Saudi Arabian airline. World Review of Business Research. 3(1), 41-51.

[41] Koech, P.M., and Namusonge, G.S., (2012). The Effect of Leadership Styles on Organizational Performance at State Corporations in Kenya. International Journal of Business and Commerce, 2(1), 1-12.

[42] Umme, S. S., Darun, M.R.\& Liu, Y. (2015). Transactional or transformational leadership: which works best for now? International Journal of Industrial Management. (20).

[43] Tengi, M. L., Mansor, M. \& Hashim, Z. (2017). A review of transformational leadership theory. International Journal of Academic Research in Business and Social Sciences.7(3). 